\title{
The restructuring of the European land armaments industry: Between political incentives and economic pressures
}

\section{Adrien Caralp}

Adrien Caralp is a doctoral student in economics at the School for Advanced Studies in the Social Sciences (EHESS), Paris, France. He may be reached at adrien.caralp@ehess.fr.

\section{Abstract}

Within the context of the restructuring of the European defense industry since the end of the cold war, this article addresses the land armaments sector in general, and armored vehicles in particular. The industry is generally divided into the aerospace, naval, land, and electronics sectors, of which aerospace and electronic are highly internationalized while the land and naval ones remain fragmented and nationally based. Economic characteristics of the land armaments industry—lower R\&D costs and longer production runs - still permit the predominance of a nationally-focused production model, yet post-cold war market changes toward lighter platforms, and resulting synergies with the civilian truck industry, imply a comparative weakening of state sovereignty and, consequently, stronger market contestability as compared to the other defense industry sectors.

$\mathrm{T}$ his article is about the restructuring of the European land armaments industry, with an emphasis on the armored vehicle sector. While the European defense electronic and aerospace industries generally are viewed as consolidated and internationalized, the land armaments and naval industries are seen as fragmented, even on a national basis. Fragmentation is often seen as a weakness, even a threat from a market-driven perspective, but can also be seen as a logical and potentially positive consequence of the primacy of political factors in military equipment choices. In a context of ever-tougher budget pressures and rising international competition, however, the current industrial organization at work in Europe is once again in question.

Apart from fragmentation, the research question addressed in this article concerns the specifics of the land armaments as compared to the other European military industries. Why do political incentives seem to be stronger in the land armaments industry, which is not of any more strategic importance than the others? I address this question in the context of theoretical debates on the scale of globalization, denationalization, and liberalization processes at work in the defense sector, and I use a regulation framework to question the way the European land armaments industry is regulated in the current environment: should it be national, pan-European, or even multinational beyond Europe?

The following sections discuss the current situation and the restructuring of the European land armaments industry. The article describes the sector's main features and general trends and focuses on the main developments aimed at creating a more integrated industry. The final section concludes the article.
Literature review and theoretical framework

While only a few studies are devoted to the European land armaments industry, four documents in particular allow us to characterize the state of knowledge and to identify the main issues and debates.

\section{State of knowledge}

A decade after the end of the cold war, a Swedish researcher (Andersson, 2001) suggested that due to a particular mix of political and economic reasons, the European land armaments industry has followed a path that differentiates it from those of other armament sectors. These include the modest increase in $\mathrm{R} \& \mathrm{D}$ costs, when compared to military aeronautics, together with the comparatively longer production runs for the land systems. This situation "made it financially possible to maintain nationally focused land armaments programs and production facilities throughout the Cold War. Without very strong economic pressure, it has proved politically difficult for governments to overcome the vested interests of groups that benefit more from local production than from European cooperation" (p. 24). Governments played a crucial role since, unlike the commercial pressures that apply to aerospace, the European land armaments sector was less diversified. But the end of the cold war and the resulting upheaval in European armies altered market conditions. The focus shifted to smaller and lighter forces, and growing competition from new entrants, and the impact of the revolution in military affairs on R\&D costs implied that "Europe's land armaments industry is presently struggling with problems similar to those that aerospace companies have learnt to live with since the 
mid-1960s" (p. 25). Andersson thus believes that a deep restructuring process will necessarily happen: "There are simply too many companies chasing too few contracts" (p. 26).

In a 2009 report, the Western European Union took a different view. Despite overcapacity and fragmentation inherited from the cold war, it believes that the relatively large number of companies in the land armaments sector is a sign of dynamism, competition, the lure of profit, and that cooperation goes together with competition. The emphasis is put on a specific military vehicle segment: "There is one category in this range that is of particular interest to us: the $6 \times 6$ or $8 \times 8$ wheeled vehicles. They are the most in demand, attract the lion's share of investment and are the main focus of technological research and development" (p. 2). The authors note the then-existence of some 23 national armored vehicles programs within the EU, of which only one - the Dutch-German "Boxer"-was produced under international cooperation (see Appendix). They further note that "the lack of joint programs is largely due to the mixed feelings generated by experiences from past years, in particular during the 1990s" (p. 3) and conclude that this situation has taught us that cooperation needs to be based upon a really shared operational foundation but does not have to be an end in itself, nor the sole expression of a political scheme of European integration.

In 2012, a Spanish consulting firm released a report for the European Federation of Trade Unions, IndustriAll. It states that "European countries are traditionally favouring the principles of national sovereignty and comprehensive autonomy in defence-related issues" (p. 14) and that despite a trend toward some degree of consolidation, "compared to the USA land armament sector, the EU has 'too many' smaller nationally-based prime integrators producing the same type of products" (p. 41). The report continues: "This persisting lack of Europeanization of the industry (combined with a limited cooperation at EU level between enterprises) results in a number of undesired side effects from an aggregated European perspective in terms of unnecessary duplication of products, production structures and research and development efforts, shorter production runs ... excess capacity as well as a lack of standardisation of military equipments" (p. 42). Yet "it is important to recognise that some EU Member States (e.g. Sweden, Germany, United Kingdom) are moving from a biased sourcing strategy towards a more open and competitive procurement strategy seeking less 'tailored' products with specifications set from the start and with less/no bias towards national sourcing" (p. 42). From a corporate perspective also, "some of the leading enterprises within the European land armament sector are starting to develop new business models that allow them to work effectively across national borders" ( $p$.
The article describes the European land armaments sector's features and trends and focuses on the main developments aimed at creating a more integrated industry. Even though there are good economic and political reasons for its current fragmentation and nationally-based production model, market and product changes put the industry's model into question.

47). The authors then elaborate on two possible scenarios, either to place priority on the Europeanization of the land armaments industry or on the maintenance of existing national sovereignty and industrial capacities. The authors favor the first option, "the development of a stable European home market that clearly surpasses the current national market boundaries" (p. 109).

Finally, a French report (Fleurant and Quéau 2014) also remarks on the issue of fragmentation. Unlike the 1990s, the 2000s were a flourishing period for this sector, it states. The multinational military operations in Afghanistan and Iraq, together with the economic growth of emerging countries, resulted in export revenue booms for Western producers. Such success did not favor industry restructuring. However, the year 2008 constitutes a turning point. The Afghan and Iraqi wars were almost completed and the economic situation of emerging countries deteriorated. European countries faced the mortgage subprime lending and debt crisis. The international economic environment became more competitive so that "as on the morrow of the end of the cold war, the European defense technological and industrial base today is in a situation of production overcapacity. The doubles are numerous in the catalogues of the various companies" (p. 35). Further, "the political issues at national level override a more market or European community driven trend" (p. 36). Duplication means higher costs at all levels (e.g., dispersion of R\&D costs, redundant production lines, reduced economies of scales, higher maintenance costs) and risks becoming internationally uncompetitive. And yet, the authors note, "more than six years after the stock market crash, the situation remains characterized by a kind of wait-and-see policy that does not seem to foresee a significant reorganization of the European production capacities" (p. 38). They then detail four possible scenarios: (1) upholding the status quo; (2) a new phase of consolidation on a national basis; (3) transnational consolidation among European actors; and (4) the setting-up of strong industrial partnerships with actors from emerging countries. ${ }^{1}$

\section{Empirical and theoretical lessons}

The views just summarized permit one to characterize the recent history of the sector. Unlike the aerospace industry, the land armaments sector is nationally focused, largely due to its 
lower capital costs and prices. The end of the cold war disrupted the situation by a combination of two factors: a fall in Western military spending combined with a shift in production toward lighter, more polyvalent vehicles. Most of the European companies succeeded in tackling these issues because of strong growth in domestic and international markets during the 2000s. Although some changes occurred in the industry, this limited the scale of its restructuring. On the one hand, the changes that did occur demonstrate dynamism and adaptive ability to a completely new operating environment; on the other hand, as market forecasts darkened toward the end of the 2000s, the issue of restructuring came up again.

From a theoretical perspective, a picture emerges of the main modalities of regulation at work in the defense sector. From world war two to the early 1990s the armaments sector is characterized by a model in which arms companies retain strong ties with their respective national governments. Governments bear the financial risks and often finance the R\&D. Emphasis is put on the performance of high technology weapons rather than on costs. With the end of the cold war, with the economic crisis of early 1990s, with globalization already at work in civilian industry, and with the continuing questioning of the role of government in private markets (since the 1980s), arms market pressure became significantly stronger. Labeled as the globalization of the defense industry, this led to doubts regarding national governments' preeminence over military affairs. In the case of the European Union, as a way to promote an integrated European defense technological and industrial base, a number of developments eventually led to a limited liberalization of the European armaments sector within the framework of a single European defense equipment market. ${ }^{2}$

Three modes of regulation can be distinguished. They will be used as an explanatory framework to understand the current situation of the European land armaments industry.

- National level regulation: No radical change compared to the previous operating environment; fragmentation remains important but does not necessarily reflect a lack of international connections and consolidation.

- Pan-European level regulation: Partial shift of responsibility from national governments to a supranational entity; more efficient resource allocation and markets; stronger strategic autonomy at the EU level, with some loss of national-level responsibilities and employment in some countries.

- Beyond-EU, multinational level regulation: Corporate shift from single-government dependency to multinational presence that allows firms to serve multiple home markets.
Table 1: European defense turnover by sector, 2006-2015, in 2006 constant EUR billions (in percent of total)

$\begin{array}{lccc} & \begin{array}{c}\text { Military } \\ \text { aeronautics }\end{array} & \text { Naval defense } & \text { Land defense } \\ 2006 & 30.0(51.9 \%) & 11.0(19.2 \%) & 17.0(28.9 \%) \\ 2007 & 43.3(60.4) & 14.4(20.1) & 13.9(19.5) \\ 2008 & 36.4(54.6) & 13.9(20.8) & 16.4(24.6) \\ 2009 & 38.0(47.4) & 17.3(21.6) & 24.8(31.0) \\ 2010 & 42.3(50.4) & 15.4(18.3) & 26.3(31.3) \\ 2011 & 37.4(46.4) & 16.3(20.2) & 26.9(33.4) \\ 2012 & 39.4(48.6) & 18.6(22.9) & 23.0(28.4) \\ 2013 & 41.4(50.6) & 18.0(22.0) & 22.4(27.4) \\ 2014 & 40.7(50.8) & 18.7(23.4) & 20.7(25.9) \\ 2015 & 40.1(47.7) & 444.0(52.3)^{*}\end{array}$

Note: * For 2014, land \& naval systems turnover are combined. Source: European AeroSpace and Defence Industries

Association (ASD), http://www.asd-europe.org/communication/ publications/facts-figures.

Europe's land armaments market: Features and trends Despite a general lack of quantitative data, two sources permit one to identify the main characteristics of the sector. In what follows, I first provide a sectoral overview and then address nationally focused firms' growing export dependency.

\section{Overview}

One overall source of sector information comes from the annual reports of the European AeroSpace and Defence Industries Association, or ASD for short (see Table 1). Available as from 2006, they provide sector-level figures for most EU members, including Turkey. ${ }^{3}$

The industry is dominated by military aeronautics. With one exception (in 2007), it generally accounts for about 50 percent of annual turnover. Next comes land defense, fluctuating between 25 to 33 percent (again except for 2007). Naval defense is in the third position, moving closer to land defense toward the end of the period.

The land armaments industry did not face a strong decline following the 2008 crisis. To the contrary, the sector enjoyed strong growth in 2009 (+51.2 percent as compared to 2008) and continued to grow until 2011. As from 2012, however, its turnover declined each year, down to EUR20.7 billion in 2014 (or 25.9 percent of total European defense industry turnover). 
This confirms the observation made earlier about the end of an armaments cycle and a trend reversal as most European arms modernization programs now are completed. Moreover, contraction of land defense turnover as from 2012 is stronger than in the aeronautics and naval sectors. The latter have seen stabilization more than diminution of turnover. Figures for 2015 are not available for land armaments, but only for the combined "land \& naval" category. At EUR44 billion, turnover is higher than in 2014 (EUR39.4 billion) but it is no longer possible to separate the shares of the land and the naval industries.

A second source of information is Eurostat, the statistical office of the European Union. Its industry classification code 29.6 comprises "manufacture of weapons and ammunition" (including military vehicles), according to the NACE classification for the period 1995-2008 (NACE Rev.1.1). Although some figures are missing, data for most of the main indicators are available for the largest producer countries. Due to a classification change in 2009 (NACE Rev. 2), the land armaments sector was divided into two main groups. The quality of the data weakens and some data are missing. ${ }^{4}$

For a handful of countries, Eurostat's available data are shown in Figure 1. The general trend shows stagnation until 2001 , then growth until 2007, a decline after 2008, followed by stagnation or an up-tick thereafter. The consequences of the 2008 crisis are more marked in the Eurostat than in the ASD data (Table 1). The market is dominated by a lead group consisting of the United Kingdom, followed by France and Germany, then Italy. A second group, at a much lower level, consists of Sweden, Spain, and Poland. A third group, not shown, has significant capabilities in land systems but not of sufficient budgetary heft to be included in the figure: They are Austria, Croatia, the Czech Republic, Finland, Romania, Slovenia and, outside of the EU, Norway and Switzerland.

\section{The search for export markets}

To sustain its predominantly nationally-focused production model-and to side-step international consolidation pressure-European countries' export sales dependency has increased. This may prove difficult to sustain, economically and politically. Unlike U.S. companies, which are less reliant on exports, Europeans see exports as a way to reap cost reductions through economies of scale and larger production runs. Exports, however, may be a "vanishing lifeline" as they are uncertain and, above all, imply a progressive knowledge drain through technology transfers to future potential competitors. ${ }^{5}$

It is unclear what impact, if any, the continuing Ukrainian crisis may have on the land armaments market. European countries may be willing to increase cooperation due to tight defense budgets and growing security threats. But if the

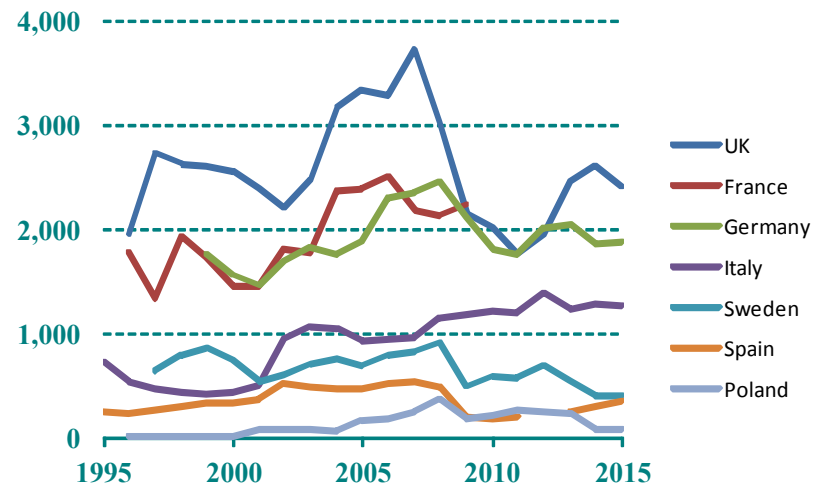

Figure 1: Inflation-adjusted turnover of the EU land armaments industry by main producing countries, 1995-2015, in 1995 constant EUR million. Notes: Data from 1995 to 2008 are those of Eurostat NACE Rev.1.1 Code 29.6, while data from 2009 to 2015 are the sum of NACE Rev.2 Code 25.4 and Code 30.4. Gaps mean that the data is not available. The inflation-adjusted turnover is calculated from the Consumer Prices- Annual Inflation series provided by the OECD for each of the seven countries (http://stats.oecd.org). Source: Eurostat (http://ec.europa.eu/eurostat/data/database).

European market for military vehicles were to exhibit growth, this may favor the status quo, as several Eastern European countries are accelerating their armored vehicle programs and, as one analyst writes, with a focus on "multiwheel-drive vehicles, as opposed to tanks, in a bid to significantly enhance the mobility capabilities of their respective land forces."

Toward a more integrated industry: Recent developments Interestingly enough, in the European land armaments sector, the first wave of cross-border consolidation was driven by a transatlantic perspective. Only recently have some ambitious intra-European consolidation projects materialized.

Transatlantic moves at the beginning of the 2000 s

Perhaps surprisingly, the main actor so far in the consolidation of the European land armaments industry is a U.S. company, General Dynamics (GD). Headquartered in Virginia, GD is stock-market listed and one of the five major American defense contractors. Also active in civilian and military aerospace, naval systems, and military electronics, GD obtained a strong foothold in the European market in the early 2000s. GD's expansion in Europe is primarily linked to the need for a medium class and air-transportable wheeled vehicle, an equipment gap identified by the U.S. Army in the 1990s as a result of its war engagements in the former Yugoslavia. Despite the capabilities of the American defense industry, "because of limited funds and an immediate operational requirement, it was decided that the new MAV [Medium Armored Vehicle] should be an off-the-shelf item already 
available on the military vehicle market." It was in this context that in August 1999 the defense division of General Motors (GM) acquired a Swiss company, Mowag, while a few months later GD took a 25.1 percent minority stake in the Austrian company Steyr-Daimler-Puch. (For decades, these two small firms of a few hundreds of employees had been involved in the manufacture of affordable armored wheeled vehicles.) A U.S. Army tender in late 1999 resulted in a contract awarded to a GM/GD consortium for a Mowag-based vehicle. Subsequently renamed Stryker, the program produced over 4,000 vehicles in North America based on the European design. ${ }^{7}$

To further diversify, i.e., to reduce its dependency on the Pentagon, GD continued its European expansion. First it acquired the main land armaments manufacturer of Spain, Santa Bárbara Sistemas (SBS), in July 2001. Until then government owned, SBS was involved in a privatization effort, and the acquisition occurred when relations between the U.S. and Spanish governments were strong. In October 2002, GD then purchased a small private German company, specializing in mobile bridges for army engineers. Further, in March 2003, GD acquired the defense assets of GM, including Mowag. In October 2003, GD fully acquired Austria's Steyr-Daimler-Puch and, in spring 2004, attempted to set up in the United Kingdom with an offer to take over Alvis-Vickers, the main British armored vehicles manufacturer. Its failure against BAE Systems, however, put a brake on GD's European expansion. ${ }^{8}$

Privately-owned and stock-market listed, BAE Systems resulted from a 1999 merger between British Aerospace and Marconi Electronic Systems. Initially specialized in aerospace and electronics, it was BAE Systems that acquired, in 2004, the already consolidated British land armaments company, Alvis-Vickers as well as its military vehicle subsidiaries in Sweden and South Africa. This acquisition was a case of home market protection (against GD) rather than a case of strategic diversification. In 2005, however, BAE Systems acquired the American military vehicle and naval gun producer United Defense Industries (UDI), at the time the biggest acquisition of a U.S. defense firm by a foreign one. With UDI, BAE Systems inherited the Swedish gun producer Bofors, which became a UDI subsidiary in 2000. In 2007, BAE Systems expanded its presence in the United States with the further acquisition of Armor Holding, a company specializing in tactical wheeled vehicles.

BAE Systems' American strategy is quite clear: gain access to the world's largest defense market. Its involvement in the consolidation of the European land armaments industry through its inherited operations in Sweden occurred by circumstance. Subsequently, the company took on a global expansion. In 2008, it set up in Australia and, although without purchasing any local companies, also increased its foothold in India and Saudi Arabia. One notable failure, however, regards its attempted merger with EADS, the European aerospace group (now called Airbus), in the fall of 2012, mostly due to the opposition of the German government.

In land systems, BAE Systems is presently under economic pressure. In America, its prospects are unsure and depend on the success of one of its main future vehicle programs. In Europe, even as the company developed the SEP-type wheeled vehicle via its Swedish subsidiary, it failed to secure contracts from either the British or the Swedish governments who instead decided to purchase foreign vehicles to reduce costs. Despite these challenges and its relatively limited contribution to cross-border restructuring, BAE Systems remains the biggest actor in the land armaments industry in Europe. ${ }^{9}$

\section{Recent moves toward increased consolidation}

Following a decade of rumors, French state-owned Nexter and German family-owned Krauss Maffei Wegmann (KMW) formed a joint venture in December 2015. Initially blocked due to German reluctance to enter into an agreement with a foreign state-owned company, it was a first step toward a binational consolidation process. Both companies are armored vehicles specialists and produce, respectively, the Leclerc and Leopard main battle tanks. Named KNDS, short for KMW and Nexter Defense Systems, the joint venture is registered in the Netherlands. If the project reaches its intended conclusion, the new entity would be Europe's second-largest land armaments actor, after BAE Systems. Presently, the integration of these two companies is partial as only a limited number of functions will be pooled: supply chain cooperation, R\&D, strategy, international marketing, sales, and communication. Both trademarks will remain. As former Nexter CEO Philippe Burtin stated when he introduced the project in France before the [lower house] Assemblée Nationale, "we must speak of a rapprochement, and not yet of a merger." The 2015 agreement plans for an initial five year period, after which the companies will decide whether or not to pursue the integration. ${ }^{10}$

To go further, the new entity will have to overcome several challenges. One is that the production lines of both companies overlap in several areas. Another is that Nexter is involved in a large modernization program for the French army so that KNDS will probably not be able to offer ambitious joint programs for the next decade or so. In the long-run, a third challenge lies in the need to strike a binational agreement on arms exports which, due to the different practices and sensitivities of the two countries, may be difficult to achieve. Finally, the recurrent issue of a possible privatization of Nexter and its modalities may constitute a stumbling block as well. 
Despite these challenges, KNDS might be the first step toward an ambitious consolidation of the sector in Europe, with the possibility to integrate other actors afterward. For example, when in December 2016 Swedish group Volvo, owner of Renault Trucks Defence, announced its intention to divest from its French military vehicles subsidiary so as to focus on its core commercial truck business, the CEO of Nexter expressed interest in purchasing the Volvo military vehicles assets in agreement with its KMW counterpart.

In addition to a possible deepening of the Franco-German deal, in March 2016, the defense division of Norwegian defense and technology group Kongsberg announced its intention to purchase a 49.9 percent stake in the Finnish defense firm Patria (with the other shares held by the Finnish government). Created early in the 19th Century, Kongsberg is 50 percent owned by the state of Norway; the rest is publicly listed. A KongsbergPatria deal, if it were to go through, would constitute a strategic alliance rather than a merger since the two companies would continue to exist as separate entities. Already they cooperate through their joint venture, Nammo-a Nordic munition, propellant, and rocket motor producer established in 1998 and jointly owned, with equal shares, by the Norwegian government and Patria. (Together, they are the second-largest northern European defense group by turnover, after Swedish aerospace and defense company Saab.) Again, if the deal goes through, defense industry cooperation between the Nordic governments would deepen and would go beyond the land sector. Patria produces armored vehicles and Kongsberg is well-known for its remotely-operated weapons station for military vehicles, for example. The new entity would also be competent in aerostructures, aerospace engine and lifecycle support, aircraft and helicopter assembly, and naval systems. One analyst wrote that "the primary objective in ongoing consolidation and merger $\&$ acquisition activity is to enhance the Nordic defense industry's competitive edge to secure big-ticket domestic and regional contracts against expected increased interest and bids from 'foreign' rivals."

\section{Conclusion}

One debate in defense economics concerns the evolution of relations between state and market in military production. Especially in the context of globalization, Europeanization, and the liberalization of the defense sector, the usual preeminence of governments over markets is challenged.

In this context, the land armaments sector remains less consolidated than the military aerospace and electronic industries because of certain specifics such as softer market pressures, lower R\&D costs, and longer production runs. From a European perspective, this means that it remains a sector where public action can be fully exerted on a national basis, the necessary and sufficient condition being the ability to secure sufficient export orders to allow indigenous defense developments to be economically viable. However, this also means that national sovereignty of the sector is actually somewhat weak when compared to the other defense industrial sectors. Consequently, market contestability seems higher in the land armaments sector than it is in the aerospace, electronics, or naval sectors. This explains how the main driver of the initial consolidation of the European land armaments industry could be an American company (General Dynamics) which established a strong foothold in Europe at the beginning of the 2000s.

\section{Appendix: An Example}

The Boxer wheeled vehicle is, thus far, Europe's only joint military vehicle program. It also is the only vehicle program to be managed by OCCAR (the French acronym for Organization for Joint Armament Cooperation), an intergovernmental organization which facilitates collaborative armament programs between and among European nations. Despite a promising start, the limited scope of the Boxer program illustrates the difficulty of cooperation in this field.

In 1994, France, Germany, and the United Kingdom initiated a joint study to meet the three countries' requirements. Two competing tri-national consortia were formed. One pooled Krauss Maffei, Wegmann, and Rheinmetall (Germany), GKN (UK), and GIAT (France); the other grouped Henschel (Germany), Vickers (UK), and Panhard \& Levassor (France). In April 1998, the three countries selected the first consortium, which subsequently took the name ARTEC (ARmoured TEChnology).

ARTEC, based in Munich, is a management and sales joint venture, production being undertaken by the participating national companies. In September 1999, however, France left the program to produce its own vehicle, the VBCI. Despite this withdrawal, a contract was signed in November 1999 by the U.K., Germany, and ARTEC for the development of the vehicle. Program management was transferred from the German procurement agency to OCCAR. The Netherlands, who received observer status in 1997, joined the program in February 2001. The ARTEC consortium then was equally owned by four partners: Alvis (UK), KMW (Germany), Rheinmetall (Germany), and Stork PWV (Netherlands), the last one being a management company set up to accommodate the Dutch involvement but without manufacturing capability. The U.K. then left the program in July 2003 on the argument that recent British military engagements showed that the vehicle under development did not fit properly into its military 
doctrine.

The project then became a Dutch-German venture, whereby the ARTEC consortium is 50 percent owned by the Dutch company Stork PWV, 36 percent by KMW, and 14 percent by Rheinmetall. 200 vehicles were ordered by the Netherlands and 270 by Germany. At this point, the program is marked by transnational consolidation that sees the small Dutch military vehicle industry being integrated into its German neighbor. In 2004, KMW acquired DDVS - the company in charge of assembling the Boxer vehicles for the Dutch army-and Rheinmetall purchased Stork PWV in 2008. At that point, ARTEC becomes an entirely German-owned joint venture between Rheinmetall (64 percent) and KMW (36 percent). In December 2015, the German Army ordered an additional batch of 131 Boxer vehicles. In August 2016, Lithuania signed a contract to buy 88 Boxers, thus becoming the third European country to actually acquire the vehicle. ${ }^{12}$

\section{Notes}

1. The French report is available only in French. Translations are by the author of this article.

2. Governments bear financial risks: Dunne (2009). Labeled: For instance, Devore (2013). Preeminence: Haaland Matlary and Østerud (2007). Single EU defense market: Castellacci and Fevolden (2015).

3. The ASD brochures do not include data on the military space sector. The inflation-adjusted figures are calculated from the OECD's "Consumer Prices-Annual Inflation" series available http://stats.oecd.org [accessed 14 February 2017].

4. Eurostat: Eurostat database, Structural Business Statistics, http://ec.europa.eu/eurostat/data/database [accessed 15 February 2017]. NACE: NACE is the French acronym used within the European Union industry classification system. It stands for "Statistical classification of economic activities in the European Community" http://ec.europa.eu/eurostat/statistics-explained/ index.php/Glossary:Statistical_classification_of_economic_a ctivities_in_the_European_Community_\% $\% 28$ NACE\% 29 [accessed 15 February 2017]. Classification change: Code 25.4 "manufacture of weapons and ammunition" and code 30.4 "manufacture of military fighting vehicles."

5. "Vanishing lifeline": Fleurant and Quéau (2014, p. 53).

6. Adamowski (2015).

7. Quote: Schulze and Zwilling (2007, p. 7).

8. GD's diversification: Fleurant and Quéau (2014, p. 42).

9. SEP is the Swedish acronym of Splitterskyddad Enhets Plattform which stands for Modular Armored Tactical System. The vehicle, however, remained at a prototype stage.

10. Quote: Linnenkamp and Maulny (2016, p. 3).
11. A remotely-operated weapons station is a weapons system (generally a machine gun) mounted on the top of a military vehicle and remotely operated by a gunner located inside the vehicle through a regular and a thermal imaging camera (https://www.kongsberg.com/en/kps/products/remoteweapon station). Quote: O’Dwyer (2016).

12. Appendix based on Dirksen (2010), various press articles, and the ARTEC website: http://artec-boxer.com [accessed 15 February 2017].

\section{References}

Adamowski, J. 2015. "Eyeing Russia, Eastern European Allies Expand Armored Vehicle Fleets." Defense News. 10 October 2015. http://www.defensenews.com/story/ defense-news/2015/10/10/eyeing-russia-e-europeanallies-expand-armored-vehicle-fleets/73410112/ [accessed 15 February 2017].

Andersson, J.J. 2001. "Cold War Dinosaurs or Hi-Tech Arms Providers? The West European Land Armaments Industry at the Turn of the Millennium." Occasional Papers 23. Paris: Institute for Security Studies, Western European Union. http://www.iss.europa.eu/de/publikationen/detail/ article/cold-war-dinosaurs-or-hi-tech-armsproviders-the-west-european-land-armaments-industry-at -the-turn/ [accessed 15 February 2017].

Castellacci, F. and A. Fevolden. 2015. Innovation and Liberalization in the European Defence Sector: A Small Country Perspective. Cheltenham, UK: Elgar. https://doi.org/10.4337/9781783477883

Devore, M. 2013. "Arms Production in the Global Village: Options for Adapting to Defense-Industrial Globalization." Security Studies. Vol. 22, No. 3, pp. 532-572. https://doi.org/10.1080/09636412.2013.816118

Dirksen, E. 2010. "National Defence Organisation and Defence Procurement in The Netherlands," pp. 304-319 in S. Markowski, P. Hall, and R. Wylie, eds. Defence Procurement and Industry Policy. A Small Country Perspective. London: Routledge.

Dunne, J.P. 2009. "Developments in the Global Arms Industry from the End of the Cold War to the Mid-2000s," pp. 13-37 in R. Bitzinger, ed. The Modern Defense Industry: Political, Economic, and Technological Issues. Santa Barbara, CA: Praeger.

Fleurant, A-M., and Y. Quéau. 2014. "Quelles perspectives pour l'industrie européenne des armements terrestres? [Which Prospects for the European Land Armaments industry?]." Focus Stratégique 50. Paris: IFRI (French Institute of International Relations). https://www.ifri.org/sites/default/files/atoms/files/fs50fle urantqueau.pdf [accessed 15 February 2017].

Haaland Matláry, J. and Ø. Østerud. 2007. Denationalization of Defence: Convergence and Diversity. Aldershot, UK: Ashgate.

IndustriAll and IKEI. 2012. "Study on the Perspectives of the European Land Armament Sector." Final Report ref. E3779 v_03. San Sebastián, Spain: IndustriAll/IKEI 
http://www.industriall-europe.eu/sectors/defence/2012/IN FF_E3779_Final\%20Report_v03-EN.pdf [accessed 15 February 2017].

Linnenkamp, H. and J-P. Maulny. 2016. "Krauss Maffaei Wegmann Nexter: A Rapid Integration as the Key for a Real Marriage." Paris: ARES Group. http://www.iris-france.org/wp-content/uploads/2016/06/C omment-KMW-Nexter-June-2016.pdf [accessed 15 February 2017].

O’Dwyer, G. 2016. "Industry Consolidates As Nordic States Unify On Defense." Defense News. 11 November 2016. http://www.defensenews.com/articles/industry-consolidat es-as-nordic-states-unify-on-defense [accessed 15 February 2017].

Schulze, C. and R. Zwilling. 2007. Stryker Interim Armored Vehicle. Hong Kong: Concord.

Western European Union. 2009. "European Armoured Vehicles: Current Programmes." Report A/2034. Paris: European Security and Defence Assembly. 